\title{
PROFIL PERMASALAHAN SISWA SEKOLAH MENENGAH PERTAMA (SMP) NEGERI DI KOTA BOGOR
}

\author{
Weni Nur Wendari ${ }^{1}$ \\ Aip Badrujaman ${ }^{2}$ \\ Atiek Sismiati S. ${ }^{3}$
}

\begin{abstract}
Abstrak
Tujuan penelitian ini adalah untuk mengetahui gambaran permasalahan siswa SMP Negeri di Kota Bogor. Populasi penelitian berjumlah 16. 228 siswa dengan menggunakan teknik sampling insidental dan jumlah sampel yang diambil 386 siswa. Instrumen yang digunakan dalam penelitian ini adalah kuesioner. Uji coba instrumen dalam penelitian ini adalah uji validitas dan uji reliabilitas. Uji validitas butir instrumen penelitian menggunakan rumus korelasi product moment. Hasil uji validitas 120 butir pernyataan dengan kriteria r-tabel yang digunakan sebesar 0,28 menghasilkan butir yang valid 94 butir dan 26 butir yang drop. Uji reliabilitas dengan teknik uji administrasi sederhana menggunakan rumus alpha cronbach dan di dapatkan hasil 0,92 yang berarti bahwa instrumen memiliki reliabilitas tinggi. Analisis dalam penelitian ini dilakukan secara deskriptif kuantitatif untuk mengetahui tingkat permasalahan siswa kemudian mengkategorisasikannya dalam kategori sangat bermasalah, bermasalah dan tidak bermasalah. Hasil penelitian menunjukkan bahwa siswa SMP Negeri di Kota Bogor masuk dalam kategori bermasalah (62. 44\%). Dengan demikian guru bimbingan dan konseling dapat segera memberikan layanan secara preventif dan kuratif secara komprehensif yakni layanan dasar, layanan responsif, perencanaan individual, dan dukungan sistem kepada seluruh siswa, terutama siswa yang bermasalah.
\end{abstract}

Kata Kunci: Permasalahan Remaja, Permasalahan Siswa SMP

\section{PENDAHULUAN}

Siswa sekolah menengah pertama berada pada tahap remaja awal dengan rentang usia antara 12-15 tahun. Pada usia ini, siswa berada dalam masa pubertas, dimana terjadi transisi dan perkembangan pada dirinya baik secara fisik, psikis, maupun secara sosial (Sarwono, 2011). Siswa mulai meninggalkan peran sebagai anak-anak dan berusaha tidak tergantung pada orang tua. Fokus dari tahap ini adalah penerimaan terhadap bentuk kondisi fisik serta berupaya mengembangkan diri melalui pergaulan dengan membentuk teman sebayanya (peer group).

Perubahan dan perkembangan tersebut menjadikan siswa SMP berada pada masa yang banyak menarik perhatian karena sifat-sifat khas yang dimilikinya. Perkembangan emosi siswa pada usia remaja awal menunjukkan sifat yang sensitif dan rekreatif (kritis), emosinya sering bersifat negatif dan temperamental. Melalui interaksi sosial timbal balik dengan lingkungan yang kurang baik, mereka akan mudah tergoda untuk melakukan berbagai kenakalan.

Studi pendahuluan yang dilakukan oleh peneliti pada beberapa siswa Sekolah Menengah Pertama di Kota bogor pada 1 Oktober 2015 bahwa, dari 30 siswa yang diwawancarai menujukkan 15 siswa mengaku pernah membolos dan menyontek, 30 siswa

\footnotetext{
${ }^{1}$ Mahasiswa Program Studi Bimbingan dan Konseling FIP UNJ, weninurwendari72@gmail. com

${ }^{2}$ Dosen Program Studi Bimbingan dan Konseling FIP UNJ, aip_bj@yahoo.com

${ }^{3}$ Dosen Program Studi Bimbingan dan Konseling FIP UNJ, atiek. sismiati@yahoo.com
} 
sering meledek dan berbuat jahil pada temannya, 21 siswa merokok, dan 7 orang mencoret-coret fasilitas umum menggunakan cat semprot.

Persoalan kenakalan yang dilakukan oleh siswa SMP merupakan persoalan yang cukup serius. Sehingga dibutuhkan penanganan secara serius guna memperbaiki perilaku sosial baru agar lebih mampu diterima di lingkungan masyarakat. Disinilah dirasakan perlunya pelayanan bimbingan dan konseling disamping kegiatan pengajaran. Adanya layanan BK diharapkan bisa memberi solusi terhadap permasalahan-permasalahan yang dihadapi oleh siswa.

Dalam proses mengentaskan permasalahan siswa, guru BK harus terlebih dahulu mengetahui jenis permasalahan siswa dan melakukan analisis kebutuhan berdasarkan data yang konkret dan validitas dari data tersebut dapat dipertanggung jawabkan. Sehingga, permasalahan yang dilakukan siswa dapat diselesaikan dengan segera secara efektif dan efisien, pencegahan dapat dilakukan sedini mungkin, dan siswa dapat berkembang sesuai dengan tugas perkembangannya.

Berdasarkan latarbelakang masalah yang telah diuraikan, maka perumusan masalah pada penelitian ini adalah "bagaimana profil permasalahan siswa di Sekolah Menengah Pertama (SMP) Negeri di Kota Bogor ?". Tujuan dari penelitian ini adalah untuk mendapat gambaran empirik siswa Sekolah Menengah Pertama (SMP) Negeri di Kota Bogor tahun ajaran 20152016 terkait permasalahan siswa SMP.

\section{LANDASAN TEORETIK REMAJA}

Remaja mempunyai arti yang luas mencakup kematangan mental, emosional, spasial dan fisik. Remaja diartikan sebagai masa perkembangan transisi antara masa anak dan masa dewasa yang mencakup perubahan biologis, kognitif dan sosial emosional (Santrock, 2001).

Masa remaja merupakan masa penuh goncangan dan tantangan, suatu periode dimana perubahan fisik, intelektual, dan emosi yang terjadi menimbulkan kekecewaan dan tekanan dalam diri individu dan konflik antara individu dengan masyarakat. Kurang stabil dan kurang terprediksinya peran-peran yang diharapkan seiring dengan terjadinya perubahan-perubahan dalam masyarakat, akan menjadikan proses peralihan dari masa anak-anak menuju masa dewasa menjadi lebih sulit. Monks membagi remaja menjadi tiga kelompok usia, yaitu remaja awal (12 sampai 15 tahun), remaja pertengahan (15 sampai 18 tahun), dan remaja akhir (18 sampai 21 tahun). (Monks, 2006)

Tugas-tugas perkembangan pada masa remaja, antara lain:

1. Mencapai hubungan baru dan yang lebih matang dengan teman sebaya baik pria maupun wanita. Tugas perkembangan pada masa remaja menuntut perubahan besar dalam sikap dan perilaku anak.

2. Mencapai peran sosial pria dan wanita. Perkembangan masa remaja yang penting akan meggambarkan seberapa jauh perubahan yang harus dilakukan dan masalah yang timbul dari perubahan itu sendiri.

3. Menerima keadaan fisiknya dan menggunakan tubuhnya secara efektif. Seringkali remaja sulit menerima kondisi fisiknya apabila sejak kanak-kanak mereka sudah memiliki konsep fisik yang diagungkan.

4. Mengharapkan dan mencapai perilaku sosial yang bertanggungjawab. Menerima peran seks dewasa yang diakui masyarakat tidaklah sulit bagi laki-laki, tetapi berbeda halnya dengan perempuan, karena sebagai anak-anak merka diperbolehkan memainkan peran sederajat.

5. Mencapai kemandirian emosional dari orangtua dan orang-orang dewasa lainnya. Kemandirian emosi tidaklah sama dengan kemandirian perilaku.

6. Mempersiapkan karir ekonomi. Kemandirian ekonomi tidak dapat dicapai 
sebelum remaja memilih pekerjaan dan memepersiapkan diri untuk bekerja. (Hurlock, 2001)

\section{PERMASALAHAN SISWA}

Masalah ialah suatu kesenjangan antara apa yang seharusnya terjadi dengan apa yang sudah terjadi tentang suatu perihal, atau kesenjangan antara kenyataan yang terjadi dengan yang seharusnya terjadi serta harapan dan kenyataannya (Creswel, 2002).

Secara sederhana masalah dapat diartikan sebagai sesuatu yang menghambat, merintangi, atau mempersulit seseorang mencapai maksud dan tujuan tertentu. Bentuk konkret dari hambatan atau rintangan itu dapat bermacam-macam, misalnya godaan, gangguan dari dalam atau dari luar, tantangan yang ditimbulkan oleh situasi hidup. Masalah yang timbul dalam kehidupan siswa di sekolah beraneka ragam, salah satunya masalah perkembangan individu. Pengawasan terhadap remaja harus dilakukan sedini mungkin untuk meminimalisir terjadinya masalah yang lebih besar. Selain orang tua dan lingkungan bermain, lingkungan sekolahpun juga memiliki perasan penting dalam memantau perkembangan melalui kegiatan yang dilakukan siswa di sekolah.

Siswa SMP merupakan remaja awal yang berada pada fase negatif. Secara garis besar sifat-sifat negatif tersebut yaitu, negatif dalam prestasi, baik prestasi jasmani maupun prestasi mental, dan negatif dalam sikap soial, baik dalam bentuk menarik diri dalam lingkungan maupun dalam bentuk agresif terhadap lingkungan (Yusuf, 2006). Pada masa transisi dari fase anak-anak menuju remaja awal, memungkinan siswa mengalami masa krisis, yang ditandai dengan kecenderungan munculnya masalahmasalah dan kenakalan remaja. Kondisi ini membutuhkan perhatian lebih dari berbagai pihak. Keluarga, lingkungan sosial, dan juga pihak sekolah.

ASCA (American School Counselor Association) mengungkapkan bahwa terdapat 4 Aspek perkembangan yang harus dicapai oleh siswa dengan tujuan untuk meminimalisir hambatan-hambatan siswa dalam mencapai kesuksesan yaitu, perkembangan pribadi, perkembangan akademik, perkembangan sosial, dan perkembangan karir. Keempat aspek perkembangan tersebut menjadi kompetensi dasar siswa yang jika tidak terpenuhi akan menimbulkan beragai masalah. Hal ini selaras dengan 4 bidang layanan bimbingan dan konseling:

1. Perkembangan Pribadi, diantaranya masalah kesehatan, fisik, dan perilaku konsumtif. (Enung, 2010)

2. Perkembangan Sosial, diantaranya hubungan interpersonal, perilaku moral, seksual, dan penyalahgunaan obat-obatan Terlarang (NAPZA). (Desmita, 2005)

3. Perkembangan Akademik, diantaranya konsep diri akademik, keterampilan meningkatkan belajar, dan mencapai sukses dalam belajar. (ASCA, 2004)

4. Perkembangan Karir, diantaranya mengembangkan kesadaran karir dan memperoleh informasi karir. (ASCA, 2004)

Adapun beberapa faktor yang mempengaruhi kenakalan remaja, yaitu identitas, kontrol diri, usia, jenis kelamin, harapan terhadap pendidikan dan nilai-nilai di sekolah, proses keluarga, pengaruh teman sebaya, kelas sosial ekonomi, dan kualitas lingkungan sekitar tempat tinggal. (Santrock, 2003).

\section{METODE PENELITIAN}

Tujuan penelitian adalah untuk mendapatkan gambaran empirik siswa Sekolah Menengah Pertama (SMP) Negeri di Kota Bogor terkait permasalahan siswa SMP. Penelitian dilakukan pada bulan November 2015 - Desember 2015 di 17 SMP Negeri di Kota Bogor.

Metode penelitian yang digunakan adalah deskriptif dengan jenis penelitian survei. Populasi dalam penelitian ini adalah siswa kelas VII, VIII dan IX SMP Negeri di Kota Bogor dengan jumlah keseluruhan 16. 228 siswa. Sampel dalam penelitian ini berjumlah 386 siswa dengan menggunakan 
rumus Slovin. Teknik sampling yang digunakan adalahinsidental sampling yang termasuk ke dalam jenis probabilitysampling teknik pengambilan sampel yang memberikan peluang yang sama bagi setiap unsur (anggota) populasi untuk dipilih menjadi anggota sampel (Sugiyono, 2011).

Penelitianinimenggunakankuesioner "Permasalahan Siswa" yang merujuk pada 4 aspek kompetensi perkembangan siswa yang dikemukakan oleh $A S C A$. Setelah dilakukan uji coba menggunakan rumus korelasi product moment pada 80 siswa SMP Negeri didapat 94 item yang valid dan 26 item yang drop. Sedangkan berdasarkan rumus Alpha Cronbach didapat nilai reliabilitas sebesar 0.92 yang diinterpretasikan memiliki reliabilitas sangat tinggi.

\section{HASIL DAN PEMBAHASAN}

Hasil penelitian menunjukkan bahwa sebagian besar (62.44\%) siswa SMP Negeri memiliki tingkat permasalahan yang berada pada kategori bermasalah (sedang), 4 siswa (1.04\%) berada pada kategori sangat bermasalah (tinggi), dan 141 siswa (36. $53 \%$ ) berada pada kategori tidak bermasalah (rendah).

Tabel 1

Kategorisasi

\begin{tabular}{cccc}
\hline \multicolumn{2}{c}{ Kategorisasi } & Fr & $\%$ \\
\hline $\begin{array}{c}\text { Sangat Berma- } \\
\text { salah }\end{array}$ & $>220$ & 4 & $1.04 \%$ \\
Bermasalah & $140-$ & 241 & 62. \\
Tidak Berma- & 220 & & $44 \%$ \\
salah & $<140$ & 141 & 36. \\
Total & & 386 & $100 \%$ \\
\hline
\end{tabular}

Grafik 1

Permasalahan Siswa

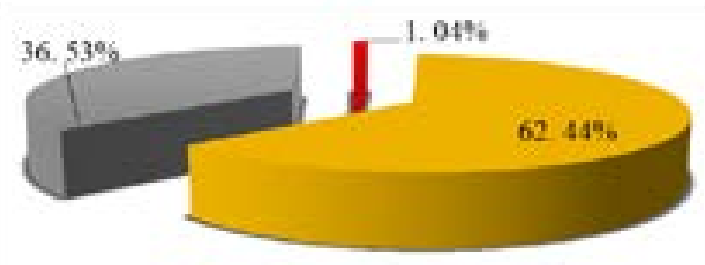

- Smangat Bermasalah $=$ Bermasalah $=$ Tidak Berrasalưh

Hasil penelitian secara keseluruhan menunjukkan $1.04 \%$ tingkat permasalahan siswa berada pada kategori sangat bermasalah atau setara dengan tinggi. Siswa pada kategori sangat bermasalah artinya memiliki perilaku yang merugikan diri sendiri dan orang lain. Terdapat kesenjangan antara kenyataan yang dilakukan oleh siswa dengan harapan perilaku dalam masyarakat yang dilakukan secara terus-menerus di hampir setiap aspek dan indikator. Senada dengan pernyataan W. Creswell Jhon bahwa masalah ialah suatu kesenjangan antara apa yang seharusnya terjadi dengan apa yang sudah terjadi tentang suatu perihal, atau kesenjangan antara kenyataan yang terjadi dengan yang seharusnya terjadi serta harapan dan kenyataannya. Siswa yang berada pada kategori bermasalah (sedang) mencapai persentase $62.44 \%$. Siswa dengan tingkat permasalahan berada pada kategori bermaslah (sedang) artinya memiliki perilaku yang menghambat, menganggu, dan merintangi diri untuk mencapai suatu tujuan serta merugikan diri sendiri dan orang lain.

Andi Mappiere juga mengungkapkan bahwa perilaku menyimpang disebut juga dengan tingkah laku bermasalah. Tingkah laku bermasalah masih dianggap wajar jika hal ini terjadi pada remaja. Maksudnya, tingkah laku ini masih terjadi dalam batas ciriciri pertumbuhan dan perkembangan sebagai akibat dari perubahan yang terjadi pada remaja secara fisik dan psikis. Berdasarkan analisis permasalahan siswa secara keseluruhan juga menunjukkan masih adanya siswa yang masuk dalam kategori tidak bermasalah (rendah) sebesar 36. 53\%. Siswa pada kategori tidak bermasalah atau tingkat 
permasalahannya rendah artinya memiliki gambaran perilaku yang tidak menyimpang dan bertolak belakang di hampir setiap deskriptor-deskriptor permasalahan siswa SMP. Hal ini menunjukkan perilaku yang baik dan siswa mampu menyesuaikan diri dengan segala perubahan dan perkembangan baik secara fisik maupun psikis,

Data hasil penelitian yang menunjukkan bahwa siswa SMP berada pada kategoribermasalahsenadadenganpernyataan yang dikeluarkan oleh Lembaga Penelitian Amerika RAND yang menyebutkan bahwa jenjang sekolah menengah merupakan masa kritis bagi remaja awal. Perilaku bermasalah siswa meningkat pada sekolah menengah dan disebut-sebut sebagai penyebab terjadinya keterasingan remaja, dikeluarkan dari sekolah, dan prestasi rendah.

Hasil data penelitianmenunjukkan bahwa sebagian besar siswa kelas VII $(65,22 \%)$, VIII $(65,97 \%)$, dan IX $(55,91 \%)$ berada pada kategori bermasalah. Banyaknya jumlah siswa di setiap kelas dengan keberagaman yang terdapat di dalamnya (agama, budaya, tingkat ekonomi dll), tentunya dapat memberikan dampak negatif maupun positif. Siswa yang tidak mampu menyesuaikan diri tetunya akanmenunjukkan sikap atau perilaku yang tidak sesuai. Guru BK yang hanya berjumlah 2-4 orang disetiap sekolah tidak sebanding dengan jumlah siswa, yang secara langsung maupun tidak akan mempengaruhi perhatian guru BK terhadap siswa. Berdasarkan observasi yang dilakukan, peneliti juga menemukan masih ada guru BK yang memiliki tugas lain yaitu sebagai Pembina ekstrakulikuler dan kesiswaan.

Berdasarkan jenis kelamin menunjukkan bahwa siswa perempuan memiliki permasalahan yang cenderung lebih tinggi atau bermasalah dari pada laki-laki. Perbedaan yang menonjol antara laki-laki dan perempuan terletak pada arah pengenalan masalahnya. Siswa laki-laki cenderung suka menerapkan pendekatan baru sehingga memiliki lebih banyak cara memecahkan masalah dibandingkan siswa perempuan. Selain itu, siswa laki-laki tidak mudah terpengaruh oleh hal-hal yang tidak relevan dengan permasalahannya, sehingga tetap fokus pada apa yang menjadi tujuan pemecahan masalah (Bastable, 2002).

\section{KESIMPULAN DAN SARAN}

Berdasarkan hasil penelitian dapat disimpulkan bahwa, permasalahan siswa SMP Negeri di Kota Bogor secara keseluruhan berada pada kategoribermasalah $(57,65 \%)$. Tiga indikator yang memperoleh persentase permasalahan tertinggi, yaitu memperoleh informasi karir, meningkatkan keterampilan belajar, dan konsep diri akademik.

Saran bagi guru BK diharapkan dapat memberikan layanan dasar dalam bidang karir agar siswa dapat mengenali diri dan keterampilan yang dimiliki, menggambarkan keterampilan dan menghubungkannya dengan berbagai minat dan bakat atau perencanaan masa depan, dan pengenalan sekolah lanjutan (SMA/SMK) serta bagaimana mengatur waktu dan berkonsentrasi dalam belajar terhindar dari rasa cemas menghadapi UN. Dukungan guru kelas dalam memberikan kesempatan pada siswa untuk mengikuti layanan BK, dan mengalihtangankan siswa yang memerlukan layanan kepada guru BK.

Orang tua juga diharapkan dapat bekerjasama dengan pihak sekolah dalam memberikan informasi terkait kegiatan belajar siswa dan perilakunya sehari-hari. Dan siswa juga diharapkan dapat mengikuti setiap layanan yang diberikan oleh guru BK dan segera melapor kepada guru atau orang tua seandainya memiliki masalah.

\section{DAFTAR PUSTAKA}

American School Counselor Association. (2004). ASCA National Standards for Students. Alexandria, VA: ASCA.

Bastable, S. (2002). Perawat Sebagai Pendidik: Prinsip-prinsip Pembelajaran dan Pengajaran. (G. Wulandari \& G. Widiyanti, Trans. ). Jakarta: EGC. (Original work published 1997) 
Creswell, J.W. (2002). Research Design. Jakarta: KIK Press.

Desmita. (2006). Psikologi Perkembangan. Bandung: Remaja Rosdakarya.

Fatimah, E. (2010). Psikologi Perkembangan (Perkembangan Peserta Didik). Bandung: CV Pustaka Setia.

Monks, J.F. , Knoers, P. M. , \& Haditono, R.S. (2006). Psikologi Perkembangan: Pengantar Dalam Berbagai Bagiannya. Yogyakarta: Gajah Mada University Press.

Santrock, J.W. (2003). Adolescence (Perkembangan Remaja) Terjemahan. Jakarta: Erlangga.

Sarwono, S.W. (2006). Psikologi Remaja. Jakarta: Raja Grafindo Persada.

Sugiyono. (2009). Metode Penenlitian Pendidikan: Pendekatan Kuantitatif, Kualitatif, dan R\&D. Bandung: IKAPI.

Syamsu, Y. (2006). Psikologi Perkembangan Remaja. Padang: Angkasa Raya. 